\title{
Analyzing a Net Zero Energy Building (NZEB) in the Climate Zone of Australia
}

\author{
Jay Patel ${ }^{1}$ \\ ${ }^{1}$ Western Sydney University, Australia \\ *Corresponding author: Jay Patel: mymailmyid0011@gmail.com
}

\section{Abstract:}

Citation: Patel J. (2021) Analyzing a Net Zero Energy Building (NZEB) in the Climate Zone of Australia.

Open Science Journal 6(1)

Received: $14^{\text {th }}$ November 2020

Accepted: $12^{\text {th }}$ December 2020

Published: $12^{\text {th }}$ March 2021

Copyright: (c) 2021 This is an open access article under the terms of the Creative Commons Attribution License, which permits unrestricted use, distribution, and reproduction in any medium, provided the original author and source are credited.

Funding: The author(s) received no specific funding for this work

Competing Interests: The author has declared that no competing interests exists.

Net zero energy buildings (NZEBs) have gained a global importance on both commercial and research-based sectors in the past decade. Especially considering the nationally determined contributions of different countries and their international/national agreements, there is a need to make a transition towards clean energy resources. Buildings and Residential sectors are amongst the major energy consumers of Australia. But the maximum portion of the energy consumed by these buildings is lost due to construction, design, or use of appliances. A significant amount of energy can be saved through this sector, which will not only reduce energy demand, it would further remove a major load from the National Grids. This study has performed assessment of a building in the residential sector of Australia and has proposed how the use of Passive, Active techniques and adoption of the NZEB concept can help save energy consumption of residential houses. PHPP and ETU Hoffgenroth tools are used to perform the building simulations for analyzing building loads, energy consumption, and developing heat contours. The results obtained from the study show the house load of the designed building, a solar system that can take up the entire load, its financial assessment, and how the use of energy-efficient appliances and the use of passive techniques can result in improvement of energy efficiency. The results obtained from the model depicts that using passive techniques, energy efficiency improvement of $34 \%$ and $47 \%$ can be achieved for heating and cooling loads respectively. An optimally designed solar system based on the total load can provide a total revenue of 0.24 million dollars over its entire life cycle. 
Keywords: Net Zero Energy Buildings, Building simulations, Energy transition, Demand side management, Passive house planning.

\section{Introduction}

Energy plays a vital role in the development of a country. Almost all the developed and developing countries are practicing to use energy-efficient materials and techniques in their capacity to minimize the energy demand and save the total cost [1]. Since the ratio of energy consumption is very high in the residential sector, therefore it is very important to explore some energy-efficient materials and techniques in this sector. After reviewing a sufficient amount of research papers on building trends of the countries across different climates of the

world, and observing their simple yet immensely effective energy saving methodologies. We have analyzed both active and passive techniques that would impart a positive effect on the energy consumption of the country and would provide a cost-effective solution for the households.

The absence of green energy housing buildings in most countries is due to unawareness of benefits of green buildings constructions, gaps informal guidance, lack of administrative system, and lack of efforts like the implementation of PEC Building Energy Codes, Energy Performance Certificate (EPC), and Residential Building Energy Policies [2]. Due to a constantly growing energy demand in the residential sector, a policy pathway is needed for the transition towards energyefficient buildings. The key focus of this research work is to address the inefficiency of building structures and degraded comfort level in residential buildings of Australia. For this purpose, the available energy-efficient measure is necessary to assess in terms of the reduction in energy consumption and building lifecycle cost. Moreover, the use of thermal insulating materials, active and passive techniques can lower the household energy demand particularly space heating and space cooling.

A sufficient amount of research-oriented knowledge associated with our research topic is obtained by reviewing different scholarly papers from certified academic and scientific journals. The results and findings of similar type research problems and corresponding theoretical and methodological approaches are particularly focused in this literature review. Consequently, a potential gap for further study is determined. Moreover, the research methodology for current research work is established based on a substantial literature review.

This study answers the questions regarding active/passive techniques that will help achieve the target of NZEBs in Australia, policy measures and policy implications for penetrating renewables in the building sector, and the resulting economic and environmental benefits of NZEBs. The aim is to achieve a state in which buildings, during their life cycle, make only a minimal contribution to GHG emissions and thus to global warming. This state is referred to as (nearly) climate neutral. One ambition level is where a (net) zero GHG emissions balance is achieved in the life cycle of buildings and structures, while (net) zero GHG emissions with regard to the operational aspect is a sub-goal that focuses only on balancing the emissions from buildings' operation. From these goals, actual target values for the design and assessment of buildings in relation to their carbon performance can be derived. It should be stressed that carbon performance is one of several aspects of environmental performance. In addition, social and economic 
performance shall be assessed, and technical and functional requirements must be met.

A sufficient amount of research-oriented knowledge associated with our research topic is obtained by reviewing different scholarly papers from certified academic and scientific journals. The results and findings of similar type research problems and corresponding theoretical and methodological approaches are particularly focused in this literature review. Consequently, a potential gap for further study is determined. Moreover, the research methodology for current research work is established based on a substantial literature review.

As per the different reports, Australia's energy demand in the building sector has increased in the past years and special measures have been taken to control it. Although, a discrepancy is present among the different studies, most of the reports the energy consumption of Australia to be around 15-20\% of the total energy. The total energy consumption of the residential sector in Australia was approximately 299 PJ in 1990. This value further increased to 400 PJ by 2008, after which it increased less rapidly and is expected to be around only $467 \mathrm{PJ}$ by the end of 2020 [3]. While in the same years, the floor area has increased from 685 million $\mathrm{m}^{\mathrm{s}}$ to about 1682 million $\mathrm{m}^{\mathrm{s}}$. Figure 1 shows the distribution of this energy among different applications or areas.

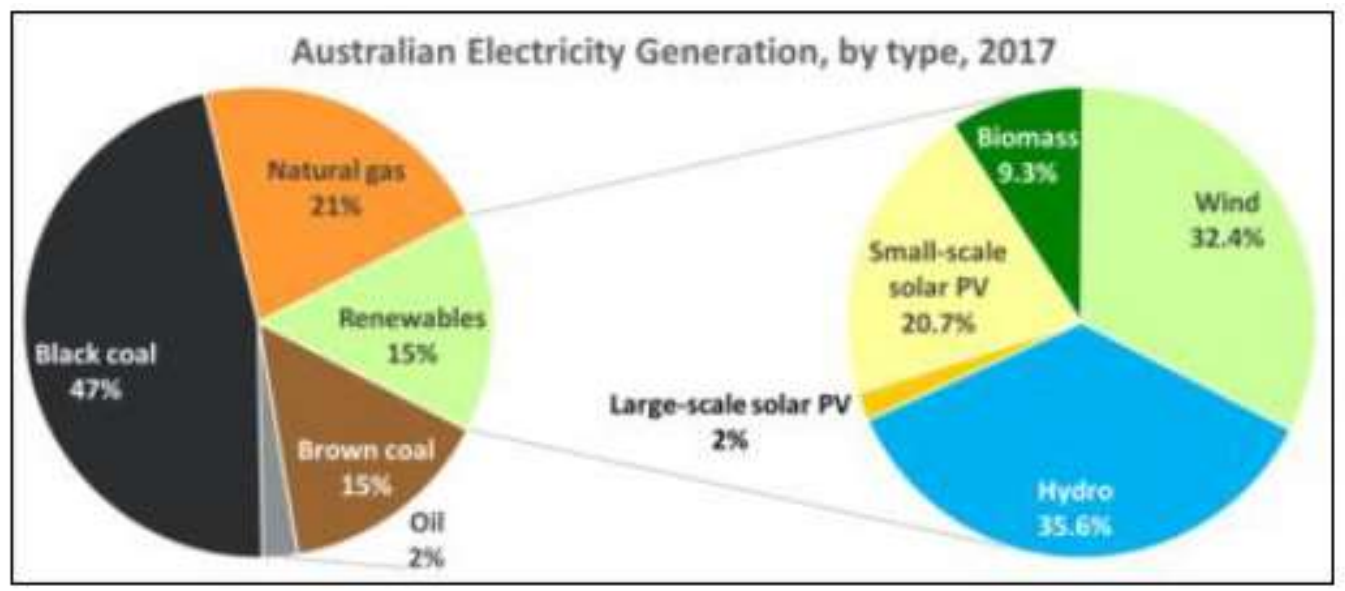

Figure 1: Share of different energy supplies in Australia's energy Mix [3]

The residential building sector, being a major consumer of the world's energy reserves has attained significant attention from policymakers for the last two decades. The rapidly growing population, increasing urbanization trend and luxurious living style of people demanding higher comfort level are key drivers of building energy demand. Globally, many residential energy policies are framed for presenting different energy-saving programs by signifying numerous potential areas and loopholes. The objective of these programs is to minimize the rapidly growing energy demand in the residential sector. In this regard, China's revised energy policies are worth mentioning because their energy-saving tendency is increased from $14.65 \%$ to $24.9 \%$ after implementation in 10 years [4]. These policies are a road map for policymakers of countries with similar climatic and demographic conditions. The policymakers must have a prior insight into existing energy demand, GDP, energy prices, per capita income level, technological development, and living standards [5]. A huge amount of energy saving can be achieved after the implementation of national energy policies in the building sector. There must be some empowered institutional framework comprising officials for inspecting newly constructed houses and retrofits as per energy codes 
and providing the construction industry with certified and labeled energy-efficient building materials for effective compliance of energy policies and codes [6].

For improving the thermal efficiency of houses and reducing their annual energy demand, several measures and policy implications have been performed. This includes the energy

savings through LEHs (Low energy house) concept, integration of renewables, and smart metering technologies [7]. In Australia, every newly constructed household must achieve a standard of at least a 6-star building under the Development Act 1993. This is one of the major reasons that future projections of household energy consumption in Australia are very much controlled. This control of demand is critical for establishing the relevant capacity of the national grid [8].

Different methodologies have been adopted to assess energy consumption. Principles of actual load monitoring have been adopted for reducing and overcoming the errors in conventional and newly built houses. This has the ultimate goal of achieving high energy efficiency which facilitates energy management. This also facilitates analyzing the peak load demand timings which provide critical interpretations and a step closer towards zero-energy buildings.

Energy consumption of the building sector is majorly consumed in the belowmentioned end uses. A share of these demand areas is shown in Figure 2.

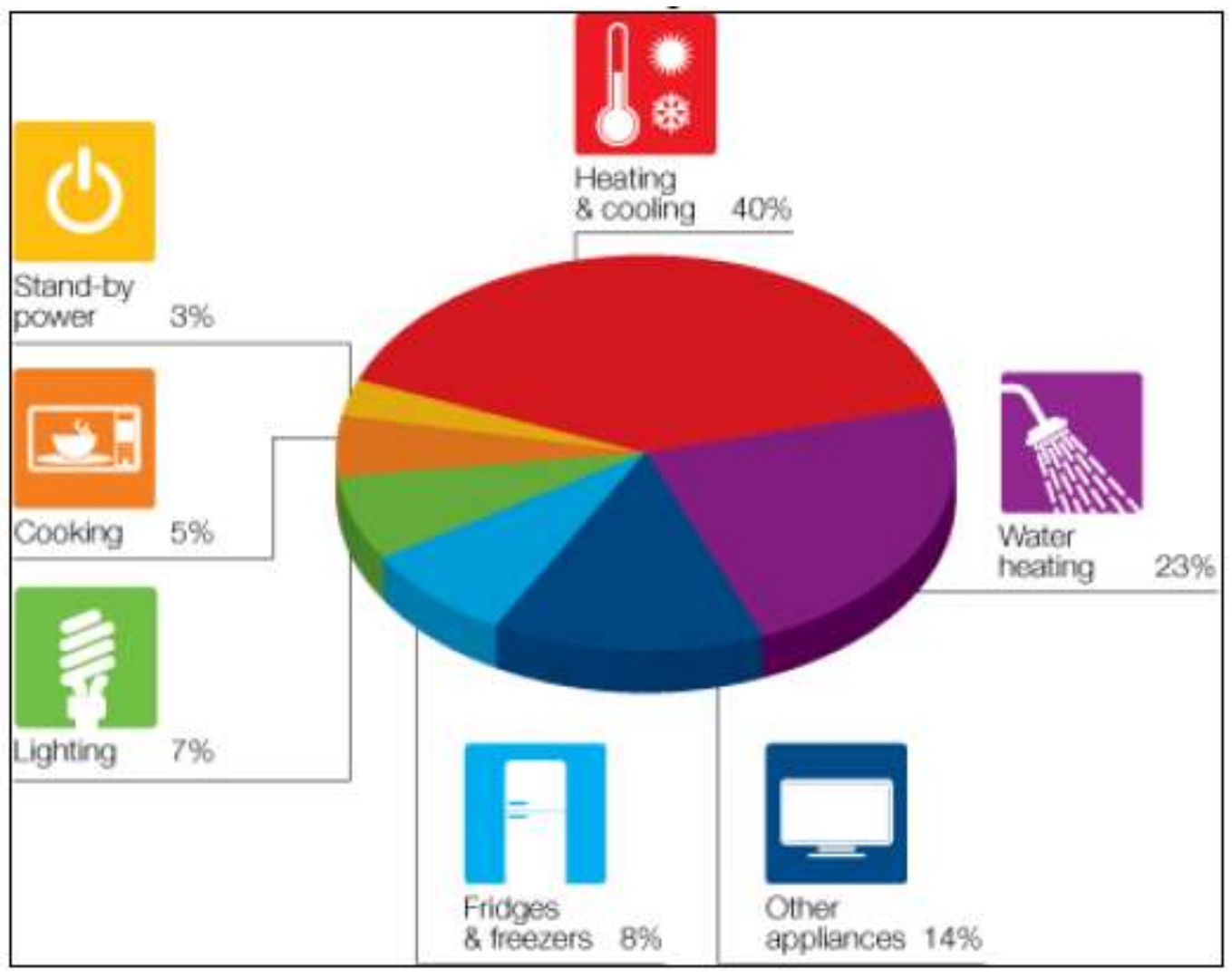

Figure 2: Share of different end-uses on total energy mix [9]. 
Various energy consumption patterns in the building sector are as mentioned below:

Space conditioning

After increasing till 2004, space conditioning in Australia has shown a comparatively downward trend till 2020. Although the stock of air conditioning equipment has shown an

upward trend, increasing from air conditioners in homes from 0.52 to 0.94 [10]. Gas heaters have now reached a saturation point, but even they had shown an increasing stock trend in the past years. Despite these factors, a positive indicator of decreasing energy demand is due to phasing out of electric resistive and wood heating to efficient reverse cycle heating devices. On average, the efficiency of ACs has increased from an ERR of 2.5 to 3.9 .

\section{Lighting}

Energy consumption through lighting showed an increasing trend even in recent years, mainly due to the increasing number of lights in an individual household. The positive image of this sector is that the inefficient incandescent lighting has phased out with the adoption of more efficient and CFLs of the years. Further, with the penetration of LEDs, the lightning subsector is also expected to show a positive upcoming trend [3].

\section{Hot water consumption}

The energy consumption of hot water has increased over the past years and is expected to follow a similar trend in the future, mainly due to an increase in residents and their uses. The sector has shown some maturity in transitioning from gas-based heaters to the solar-based heater, but still, their penetration in the current market is low. This is among the major reasons that the adoption of gas-based heaters in Australia has declined from 0.62 in FY-2000 to 0.46 in FY2013 [8]. The energy use by electric water heaters is now forecast to increase slightly, as the fuel-switching rate declines, and no other MEPS or water efficiency measures are planned to be implemented.

Electrical appliances-white goods and entertainment

Cumulative energy consumption of white goods has increased over the past years due to an increase in adoption as well as the number of appliances. An upward trend has been observed since the 2000s and is expected to continue like this. However, despite an increase, the efficiencies of these appliances have evolved over time, and it should be noted that the increase in energy demand is less than the corresponding increase in appliances and their use.

\section{Existing practices and green energy building techniques}

Since the evolution of mankind, building systems have had to own its great influence. People from different areas according to climatic conditions construct buildings to improve their way of living. In the United States, the major construction materials are cement, sand, concrete, clay bricks, concrete blocks, AAC blocks, and timber [11]. The locally available material is used for building construction in other parts of the world, for example, bamboo used in South Asia. Wood is used in many countries due to its low energy content. Many studies of various countries show that wood structures with less energy and emit less carbon emission through its lifecycle. Natural aggregates are used for the production of cement and asphalt concrete. Now, these days' coal combustion 
products such as fly ash brick are more common in the construction industry. In the USA coal fly, ash used up to $50 \%$ in the replacement of Cement [12]. In European countries timber is used for residential building due to availability and ease of construction, but clay bricks and AAC blocks are the main construction materials. AAC blocks used in commercial, industrial and residential buildings in Europe for over 90 years, in the Middle East 40 years and Australia and America about 25 years. At present, the share of AAC blocks in the building sector of Germany is more than $60 \%$ and in the UK its demand is almost $40 \%$. In Asian countries, traditional bricks are mostly used for wall structures, but AAC blocks are more common in India, China, and Bangladesh.

Green energy building techniques

Under the current scenario, energy consumption, both in developed and developing nations has gained significant attention from policymakers for future sustainability concerns due to increasing energy demand, high energy prices, and extensive environmental emissions. As the housing sector is the major consumer of the world's primary and secondary energy, therefore, suitable energy-efficient strategies are required, particularly in this sector [13]. Energy-efficient housing techniques are classified into active and passive techniques. The active techniques reduce energy consumption by increasing the efficiency of various building services such as appliances for lighting, heating, ventilation, air conditioning, and refrigeration. The passive techniques are used to improve the thermal performance of different building envelop components such as roofs, walls, floors, and windows, etc. Both techniques have significance in attaining an optimum level of thermal comfort. Human thermal comfort is associated with several different parameters such as indoor/outdoor air temperature, humidity level, air speed, metabolic activities, clothing, and physical activities. International standards such as ASHRAE 55 and EN 15251are used to evaluate human thermal comfort [14].

A building envelope separates the inside of the building from the hot or cold outside and it determines the amount of energy required for a building operation. A thermally responsive building envelop is the need of the day as it minimizes or eliminates the use of mechanical heating and cooling systems. Insulating different components of building envelop can reduce the heating and cooling demand for building up to $60 \%$ and $40 \%$ respectively. The thermal performance of different building envelope components such as walls, roofs, and fenestrations can be improved by reducing their U-Values. Different worldwide practices for treating external walls are thermal storage medium, wall insulations, and reflective coatings. Thermal storage materials are usually effective in the lightweight building envelope. It is calculated using Energy plus simulation that the use of water as a thermal storage medium inside the wall can reduce annual energy consumption by $8.6 \%$ [15]. Thermal storage medium such as PCM (phase change materials) can also significantly improve the energy performance of the building. In brick masonry walls, the use of a rat trap bond generates alternate layers of air cavities throughout the wall. These air cavities act as insulating media thus preventing the transfer of external heat inside the building during summer. Similarly, in winter, the rat trap wall reduces the heating load by retaining the internal heat of the building. Moreover, the construction cost of such walls is $25 \%$ less than conventional Flemish bond masonry due to adequate saving of building materials (25\% bricks and $40 \%$ cement) [16].

Studies have also shown how the target of NZEBs can be achieved through VC-based systems in an efficient manner [17]. Other than solar PV, triple-hybrid 
single-effect vapor absorption cooling system (VACS) has also been used for increasing the energy efficiency of buildings [18]. Energy saving potential of solar, biogas, and electric powered VAC has also been performed that leads to $9.1 \%$ of lesser energy consumption [19]. Absorption based technologies have been used to achieve $45.67-46.14 \%$ electricity savings as well [20].

Passive house concept

The basic idea of passive housing is based on "well insulated, air leak-proof, properly ventilated, and thermally bridged free envelopes. The concept was initially used for reducing the Heating Load of buildings to such an extent that no further use of active heating devices is required. Germany constructed the first Passive House in the 1990s. In the beginning, there was a misperception regarding the risk of excessive solar heat gain in the buildings complying with passive house standards, during summer. Later studies proved that optimizing few design parameters such as glazing ratios and external shadings make the passive house concept equally effective in hot climates [21].

\section{Use of renewables in zero energy buildings}

Various techniques are deployed for integrating renewable energy and energy saving alternatives in buildings as mentioned below:

\section{Photovoltaics}

For achieving the objective of zero energy buildings, previously mentioned techniques can be applied for reducing the heating load. However, in the majority of the houses, the electricity demand is larger than its heating demand. For green and zero energy buildings, that demand has to be covered by the use of renewables. In the case of photovoltaics, this is done through a system named Building Integrated Photovoltaics (BIPV) that can be applied through multiple techniques [22].

The basic principle implied is that the net electricity import and export (through solar) in a building is zero as shown in Figure 3.

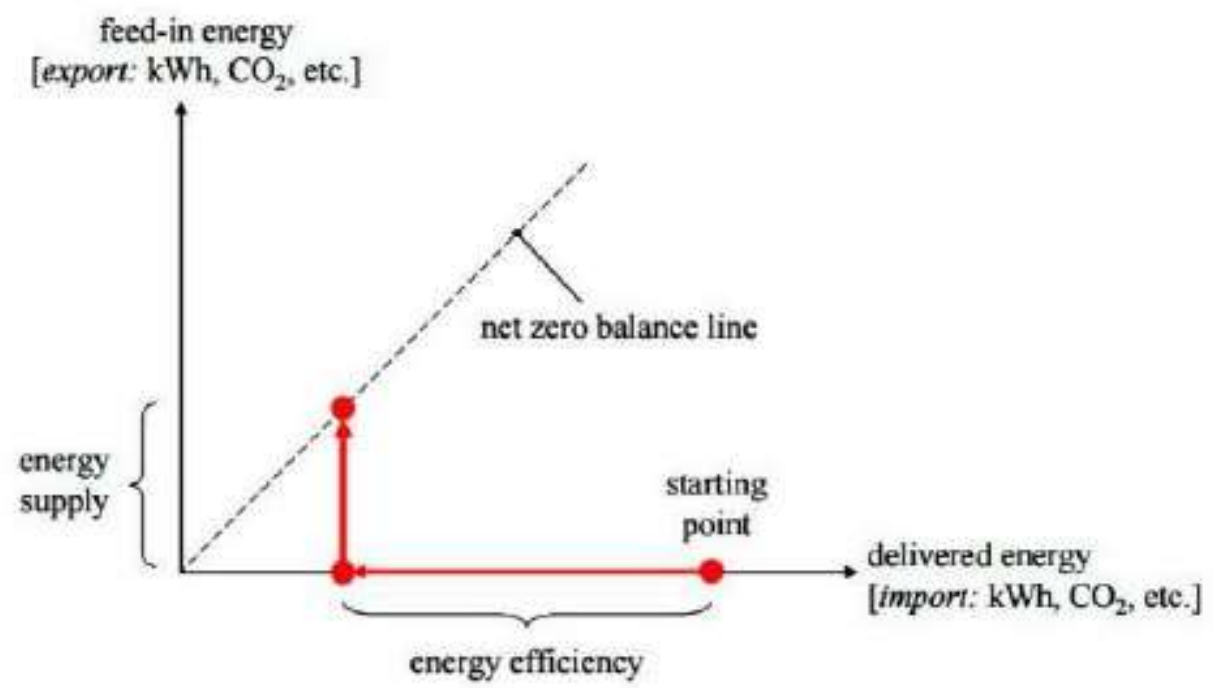

Figure 3: Graphical representation of a Net Zero Energy Balance [22] 
Hence, the purpose of NZEB can be achieved by cumulatively reducing the energy demand through efficient appliances, and producing the amount of required energy through renewables. The excess energy produced can also be connected to the National Grid, thus resulting in an Economical Benefit.

\section{Wind catcher}

Wind catchers can further be used to create natural ventilation and passive cooling in the buildings. They can significantly cut the power demand, especially for air conditioners. Literature suggests that the annual cost of a building constructed with wind catchers is lower than the building constructed using conventional heating and ventilation techniques. These machines require insignificant maintenance with a long life cycle. Another advantage of wind catchers is that they do not consume CFCs like conventional ACs that are a health hazard, and produce dry air that can harm human life [23]. Hence, wind catchers are not penetrating more rapidly in the energy technology market, and are expected to be a critical component of net-zero energy buildings.

Other renewables

Apart from solar PV, other renewable options such as biogas production from municipal solid waste, agricultural, or wood products can also be decomposed to produce biogas or biofuels for energy generation purposes. Similarly, wind catchers can be used to perform the following functions

1. Grinding applications

2. Reciprocating motion for energy conversion.

3. Small scale energy generation for powering front lights or other small appliances.

\section{Building architecture and advanced construction materials}

The energy load of a building is also dependent on the transfer of energy through the walls or roofs. In past years, much research has been performed on construction materials that save energy. One such material is Autoclaved Aerated Concrete (AAC) blocks [24].

AAC was developed in the mid-1920s by Dr. Johan Axel Eriksson an architect and innovator of Swedish. Autoclaved Aerated Concrete (AAC) is an eco-friendly and certified green building materials. It has a low weight to volume ratio, highly load-bearing capability, high thermal insulating capacity, and durable building product. The advantages of AAC blocks over clay brick are Eco friendly, low weight, energy saver, fire resistor, low maintenance, and fast construction. The density of AAC varies from $550-600 \mathrm{Kg} / \mathrm{m} 3$ as compared to $2300-2700 \mathrm{Kg} / \mathrm{m} 3$ for conventional concrete [24]. Fly ash, lime, cement, gypsum, water, and aluminum powder are used as raw materials for the manufacturing of AAC.

AAC was developed in the mid-1920s by Dr. Johan Axel Eriksson an architect and innovator of Swedish. Autoclaved Aerated Concrete (AAC) is an eco-friendly and certified green building materials. It has a low weight to volume ratio, highly load-bearing capability, high thermal insulating capacity, and durable building product. The advantages of AAC blocks over clay brick are Eco friendly, low weight, energy saver, fire resistor, low maintenance, and fast construction. The density of AAC varies from $550-600 \mathrm{Kg} / \mathrm{m} 3$ as compared to $2300-2700 \mathrm{Kg} / \mathrm{m} 3$ for conventional concrete. Fly ash, lime, cement, gypsum, water, and aluminum powder are used as raw materials for the manufacturing of AAC. 
The concept of NZEBs is sufficiently discussed in the literature as mentioned above, but most of the studies area limited to a single aspect. Some studies have touched upon the passive techniques, while other have touched upon the active techniques. This study has performed a cumulative assessment that has taken both aspects into consideration, and at the same time a solar system with net metering has been proposed that will provide further economic benefits. Next section of the study deals with the methodology adopted for analyzing data and the model development. This will be followed by the results and policy recommendations based on both national and international approach for energy savings.

\section{Methodology}

Research methodology of the stydy and its conceptual framework is represented in the figure below. This study has performed both qualitative and quantitative assessment of energy saving potential through passive housing techniques and adoption of renewable energy resources within a household. The qualitative study includes the array of various data from an assortment of sources such as biographies, contextual investigation, and individual encounters. Quantitative research consists of numerical and factual information related to research which further identifies the need how RES (solar system) can provide both financial and social incentives

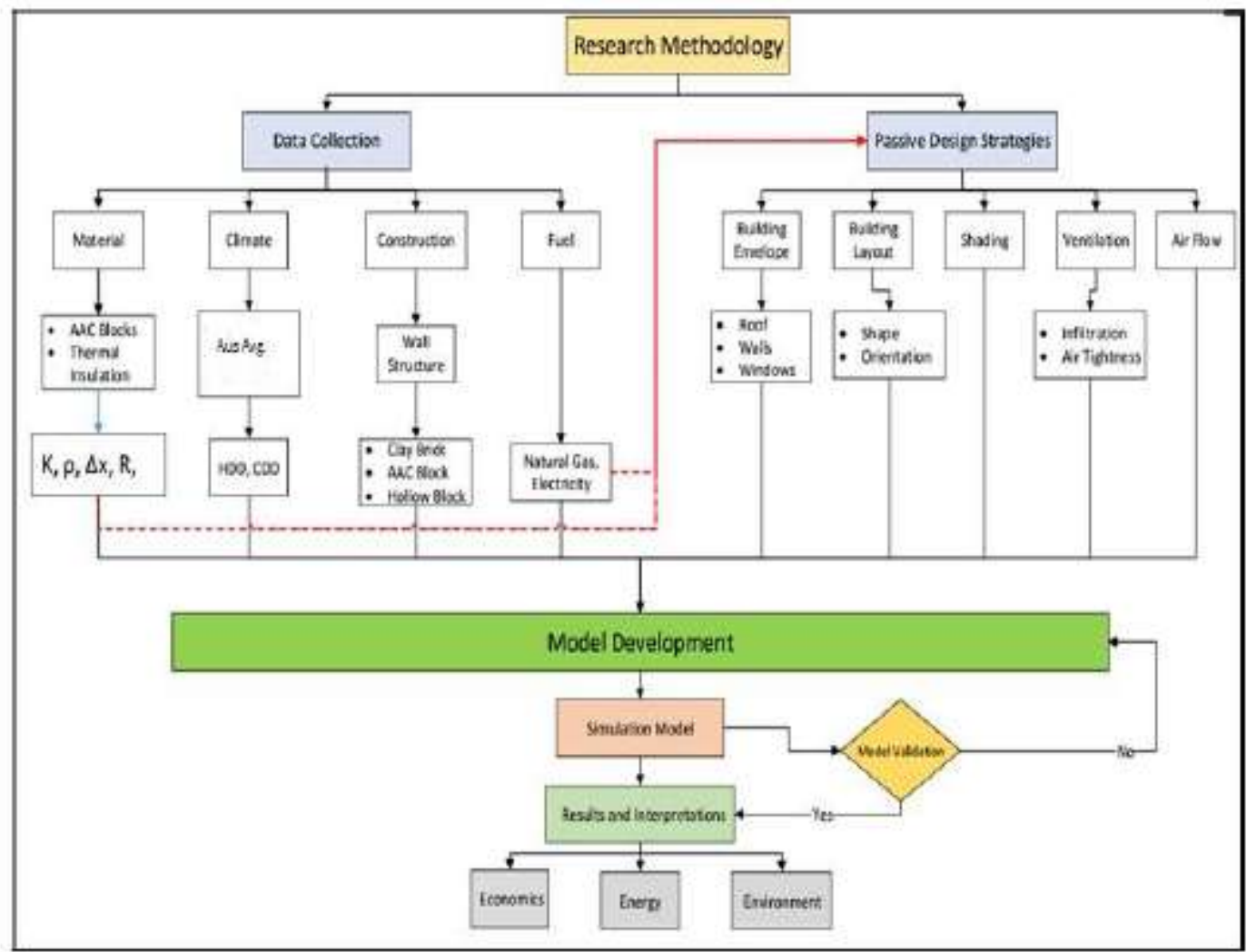

Figure 4: Methodology Flow for PHPP model development and Data Collection Process 
In this study, various parameters were involved to explore the cost-effective and energy-efficient building material which has less embodied energy and produces low carbon emission, for this purpose data is collected through some previous studies, market surveys, questionnaires, and interviews of owners of different industries and household.

\section{Data analysis}

A building model was analyzed for estimating a standard value of energy demand, investigating specialized and financial impacts of various methodologies used, effects of new advancements on energy demand, emissions, and indoor thermal comfort. Data can be analyzed by different approaches. For this research study, two types of engineering approach first deductive reasoning (Top-down Approach) and then inductive reasoning (Bottom-up Approach) was used for estimating overall building energy consumption. The top-down approach treats a building or building sector as an energy sink whose energy consumption is governed by different economic and technological attributes such as GDP, employment ratio, price of energy, energy services, income level, and use of latest technology equipment by the residents. In the bottom-up modeling approach, building energy consumption was treated as a function of different input variables such as building shape, building envelope, type of utility equipment, internal temperature, climate conditions, and occupancy pattern. Moreover, power consumption data of individual equipment and appliances were also used to assess the energy demand. The growing energy consumption in buildings is associated with different technical and social aspects such as the number of inhabitants, income level, covered floor area, heating and cooling trends of buildings, and indoor temperature.

International Energy Agency (IEA) has particularized various methods for analyzing the energy efficiency of a building. These include the prescriptive method, trade-off method, energy frame method, model building method, and energy performance method. In the prescriptive method, each component of the building is analyzed against a specific pre-defined standard value. In the trade-off method, the value of a few building parameters exceeds while the remaining do not meet energy efficiency standards. In the model-building method, initially, a building model is analyzed against set values. Then, the original building is analyzed against actual parameters. Both results are compared and the actual building should be better than the model building. In the energy frame method maximum limit of heat gain or loss is specified and the corresponding value of building parameters is calculated accordingly. In the energy performance method, the actual energy demand of the building is set according to the availability of energy, and analysis is performed thereafter [98].

The analysis in this study will be performed through the use of PHPP and ETU software using based on the following steps.

1. Geometry will be created on HottCAD of ETU where climate conditions will also be applied.

2. The ETU model will measure the overall heat transfer coefficient of the building without any appliances to get an idea of major heat consumption areas and losses. 
3. The total Energy load of that building will then be calculated using Excel Sheets. All major appliances will be considered and their approximate running hours.

4. Energy-saving through these technologies will be calculated by the mathematical model used by Ref-. Total energy savings calculated at the end of this study will be cumulative values of energy saving through both Active and Passive Techniques.

5. All building load along with its dimensions will then be inserted in PHPP software to calculate energy savings through Passive techniques.

6. The solar PV system will be used to fulfill the electricity demand of that household. Its economic assessment and evaluation will be performed through excel sheets that will describe its Payback period, annual savings, cash flow, and total revenue at the end of the solar system's lifecycle.

\section{Building design and geometry}

For performing analysis, the below-mentioned building was designed on ETUHoffgenroth software. Different views, sections and geometry of the building are as shown in the figure below
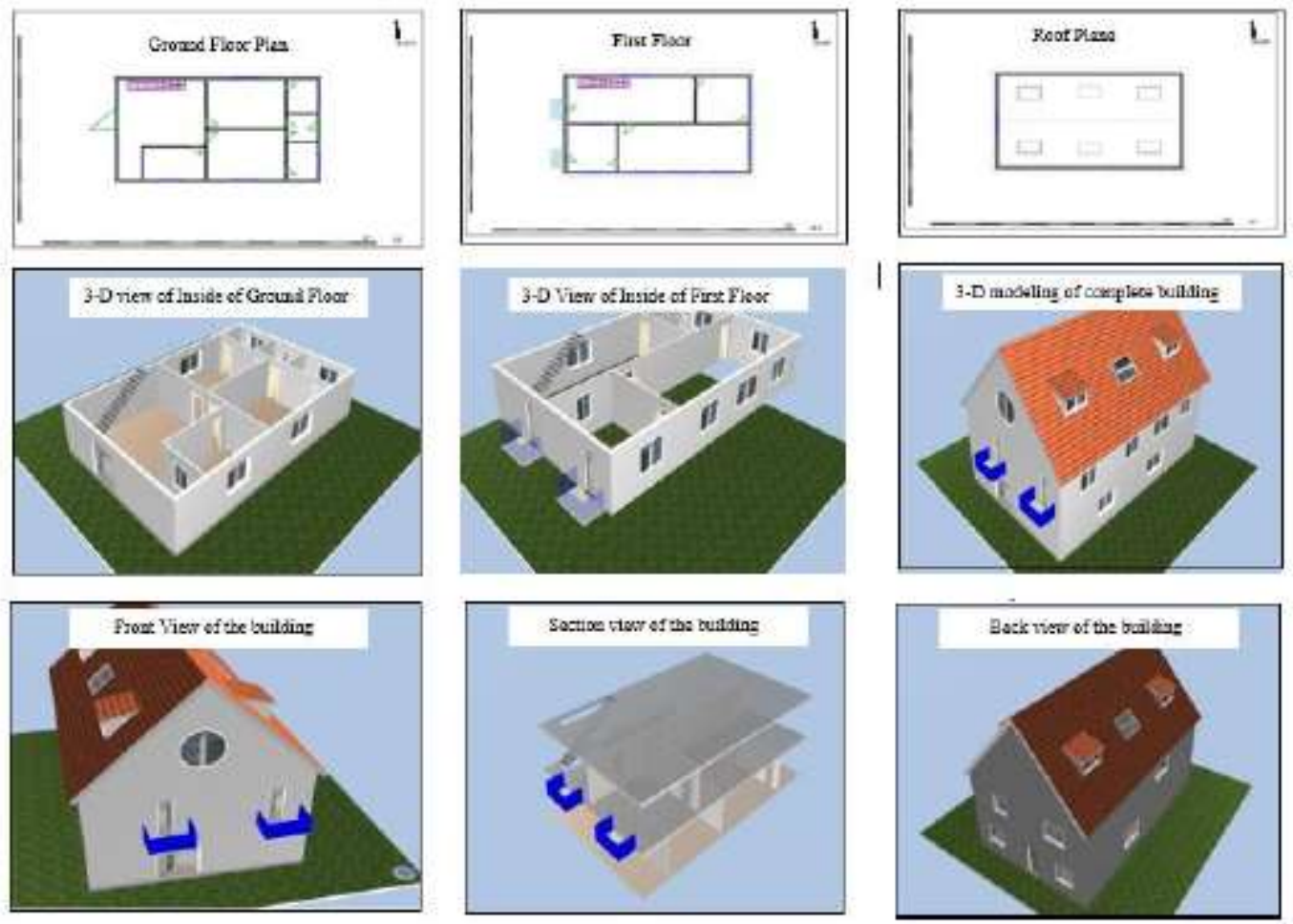

Figure 5: Geometry of the building created on ETU Hoffgenroth software

While defining the geometry, climate conditions of the environment (Australia) were also given as highlighted In figure. Along with temperature, average wind speed was taken to be $6 \mathrm{~m} / \mathrm{s}$. Area and other parameters of the building are mentioned later in the "assumption" section. 


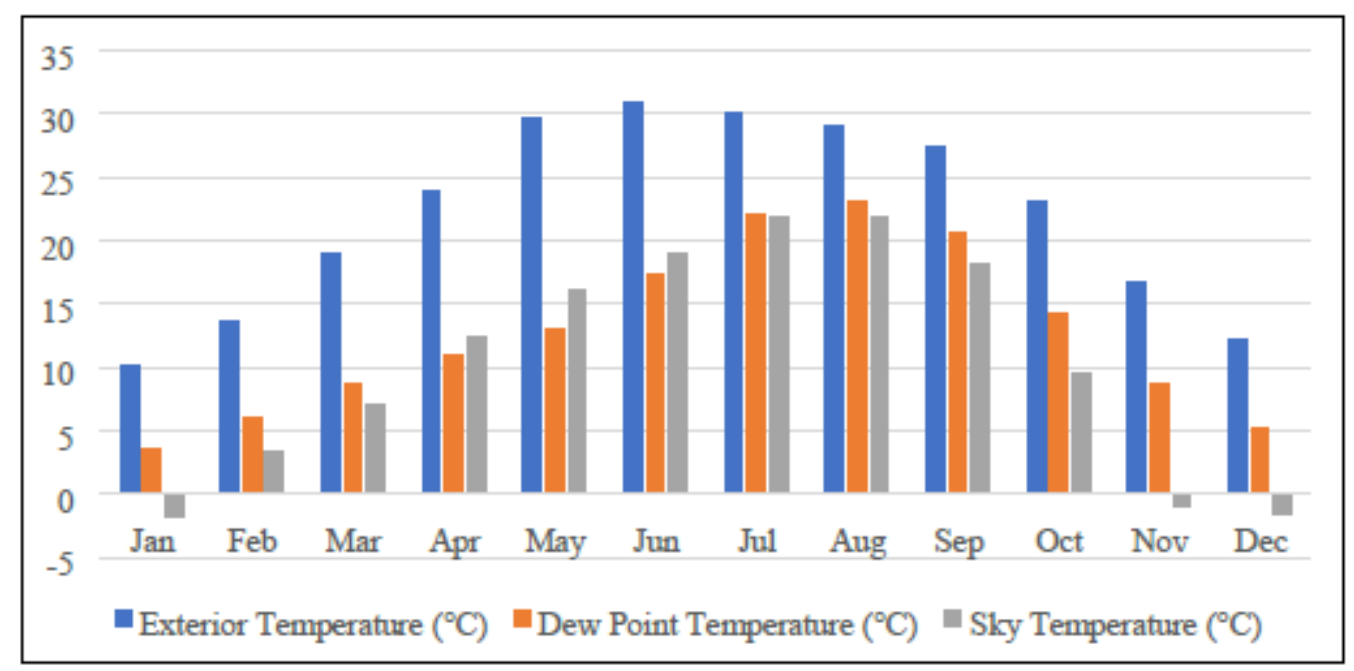

Figure 6: Average Temperature measurements in different months in Australia

\section{ETU Model}

After creating the base geometry in HotCADD, further detais regarding the building model were added. Based on an average 2-story household, total building was supposed to have 10 ceiling fans, 12 tube lights, 4 air conditioners, 2 refrigerators, 2 televisions, 6 chargers, 2 irons, 2 washing machines, 2 oven, 2 motors, 4 electric heaters, and some small electronic devices whose load was cumulated into a single device. Monthly variation of this load is shown in the figure below. Total load caulculations for one month are shown in table and the annual variations are shown in the figure.

Table 1: Load Calculations of building

\begin{tabular}{|l|c|c|c|c|}
\hline \multicolumn{1}{|c|}{ Device } & $\begin{array}{c}\text { Power } \\
\text { (Watts) }\end{array}$ & Quantity & Time (hr) & Total Energy Consumption (Wh) \\
\hline Ceiling Fans-1 & 80 & 4 & 20 & 6400 \\
\hline Ceiling Fans-1 & 80 & 6 & 5 & 2400 \\
\hline $\begin{array}{l}\text { Tubelights + Energy } \\
\text { Savers 1 }\end{array}$ & 25 & 6 & 7 & 1050 \\
\hline $\begin{array}{l}\text { Tubelights + Energy } \\
\text { Savers 2 }\end{array}$ & 25 & 6 & 3 & 450 \\
\hline Air Conditioner-1 & 1500 & 2 & 7 & 21000 \\
\hline Air Conditioner-2 & 1500 & 2 & 4 & 12000 \\
\hline Refrigerators & 180 & 2 & 8 & 2880 \\
\hline Television & 250 & 2 & 5 & 2500 \\
\hline Television-2 & 250 & 2 & 3 & 1500 \\
\hline Chargers (Mobile etc) & 45 & 6 & 3 & 810 \\
\hline Iron & 2000 & 2 & 0.5 & 2000 \\
\hline Oven & 900 & 2 & 0.5 & 900 \\
\hline Washing Machine & 800 & 2 & 0.5 & 800 \\
\hline Water Motor & 1200 & 2 & 2 & 4800 \\
\hline
\end{tabular}




\begin{tabular}{|c|c|c|c|c|} 
Electric Heaters & 2000 & 4 & 0 & 0 \\
\hline Others & 800 & 2 & 4 & 6400 \\
\hline- & - & - & Daily Avg & 65890 \\
\hline- & - & - & $\begin{array}{c}\text { Monthly } \\
\text { Avg }\end{array}$ & 2042590 \\
\hline
\end{tabular}

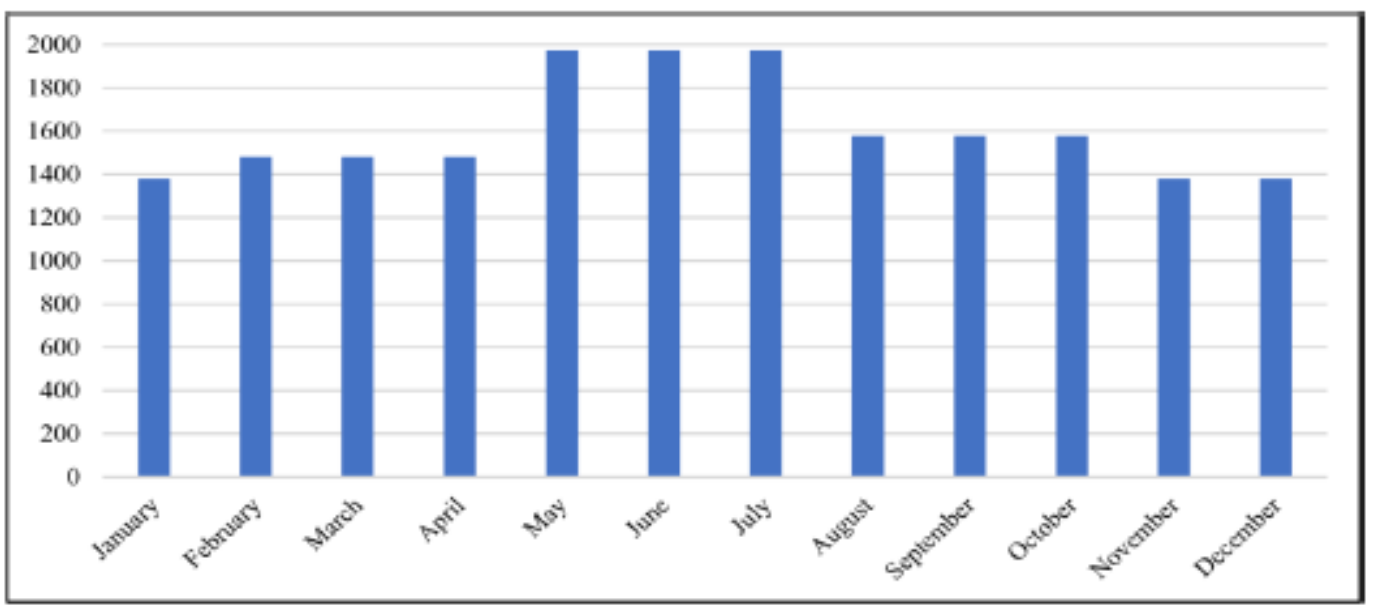

Figure 9: Monthly Variation of Load across the year

PHPP Model and Solar system calculations

PHHP model is created mainly to identify the impact of passive devices, mainly the use of AAC blocks in replacement of conventional bricks. Other than this, window glazing and shodowing are further analyzed. Based on the total load, solar system calculations are performed by taking approximations from a market survey.The solar system analysis involves calculation of the solar requirements of the building and how its utilization can provide economic benefits.

Modeling Assumptions

Each model mentioned above is linked with some assumptions and limitations, mainly due to lack of availability of data and research in that particular area. The modeling assumptions taken in this study are:

- The prices taken for economic analysis in solar system installations are actually the costs. The different between the two is linked with the market behavior.

- Life of the solar system is taken as 25 years.

- Decline in cost of solar energy production with time through panels is not taken into consideration.

- The solar production and its price is the market average and is not linked to any particular company.

- Total area of the building taken in HottCAD is $25 * 45 \mathrm{ft}^{2}$. Each window is $3 * 3 \mathrm{ft} 2$. And each door is $3 * 9 \mathrm{ft}^{2}$.

- House leaking and energy loss are same as already present in the database of ETU software.

- Conventional building is made up of clay bricks while the energy efficient buildings are made up of AAC blocks. 
- The heat generation and load consumption of in-house appliances are through a market survey and some from IEA data sets.

\section{Results and discussions}

Results obtained from the previously mentioned analysis will define the prospects of energy savings in a residential building.

\section{Results of overall heat transfer co-efficient of the building}

"U" values defines that how well a building environment is transferring the heat through a unit area. The major driving factor is the temperature between building, the environment, and the heat generation through inlet devices. Based on the model results, the " $\mathrm{U}$ " value could be as shigh as $3.5 \mathrm{~W} / \mathrm{m}^{2} \mathrm{~K}$ and as low as $0.18 \mathrm{~W} / \mathrm{m}^{2} \mathrm{~K}$.

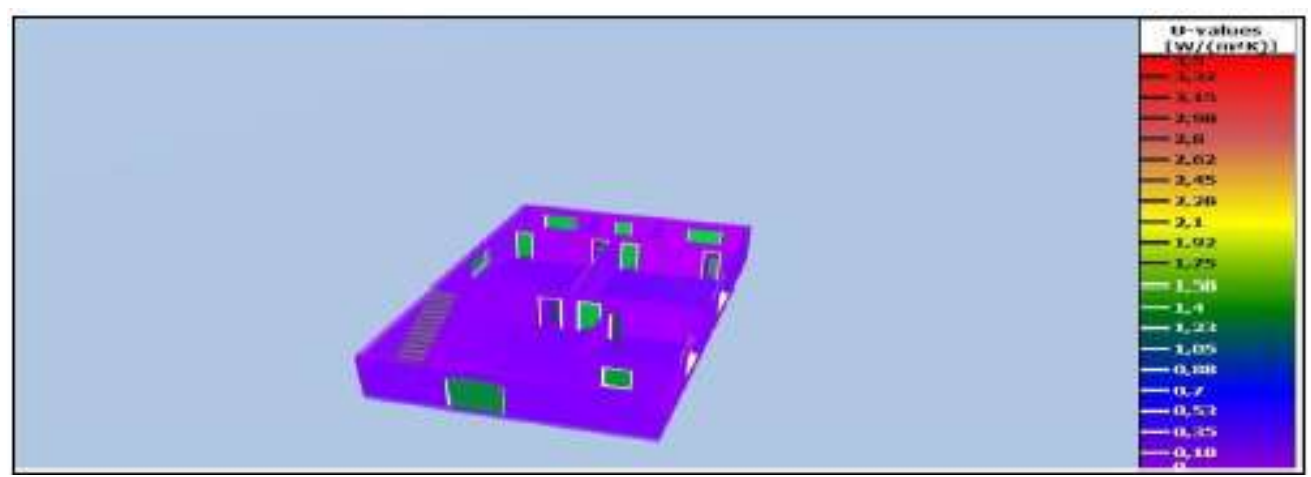

Figure 7 Value of Overall Heat Transfer Coefficient of the Ground Floor

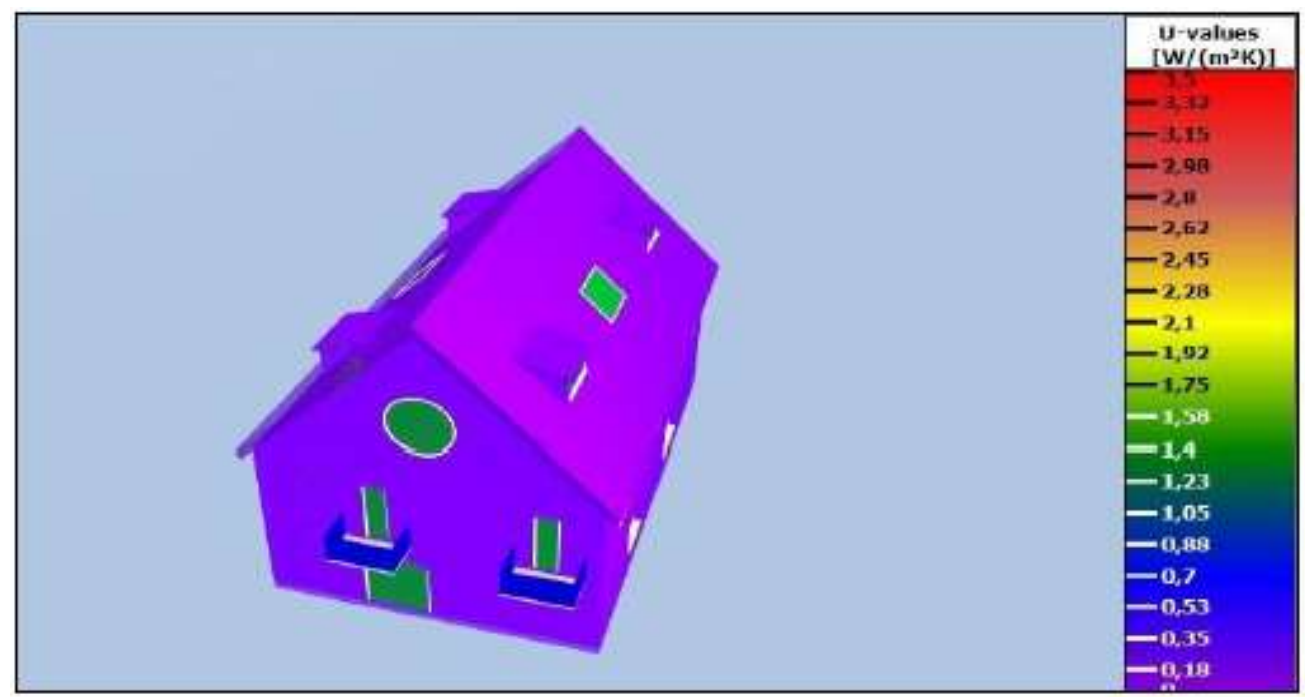

Figure 8 Value of Overall heat Transfer Coefficient of the whole building 


\section{Solar system requirements}

Based on the load calculations, the building will require a solar system size of around $8.5 \mathrm{~kW}$, if power factor is taken to be 1.3 . This solar system can be installed as a decentralized on-grid system. The solar hours and total revenue is mentioned in the table below

Table 2: On-Grid System Calculations

\begin{tabular}{|l|c|c|c|c|c|c|}
\hline Month & Consumption & Bill Savings & $\begin{array}{c}\text { Solar } \\
\text { Production }\end{array}$ & Units sold & $\begin{array}{c}\text { Total } \\
\text { Revenue }\end{array}$ & Solar Hours \\
\hline & $\mathrm{kWh}$ & Cents & Units & Cents & Cents & Monthly \\
\hline January & 1381.8 & 55272 & 1710.8 & 13160 & 68432 & 200 \\
\hline February & 1480.5 & 59220 & 1668.03 & 7501.2 & 66721 & 195 \\
\hline March & 1480.5 & 59220 & 1753.57 & 10922.8 & 70143 & 205 \\
\hline April & 1480.5 & 59220 & 2138.5 & 26320 & 85540 & 250 \\
\hline May & 1974 & 78960 & 2694.51 & 28820.4 & 107780 & 315 \\
\hline June & 1974 & 78960 & 2566.2 & 23688 & 102648 & 300 \\
\hline July & 1974 & 78960 & 2395.12 & 16844.8 & 95805 & 280 \\
\hline August & 1579.2 & 63168 & 2181.27 & 24082.8 & 87251 & 255 \\
\hline September & 1579.2 & 63168 & 2395.12 & 32636.8 & 95805 & 280 \\
\hline October & 1579.2 & 63168 & 2463.552 & 35374.08 & 98542 & 288 \\
\hline November & 1381.8 & 55272 & 2052.96 & 26846.4 & 82118 & 240 \\
\hline December & 1381.8 & 55272 & 1710.8 & 13160 & 68432 & 200 \\
\hline
\end{tabular}

Complete cash flow of this system is shown in the table below

Table 3: Cash Flow of Solar PV system and Net benefits

\begin{tabular}{|c|c|c|c|c|c|}
\hline Year & Payments & $\begin{array}{c}\text { Total } \\
\text { Savings }\end{array}$ & $\begin{array}{l}\text { Payment } \\
\text { Recovered }\end{array}$ & System Cost & 855400 \\
\hline 0 & -855400 & & -855400 & $\begin{array}{l}\text { Efficiency } \\
\text { decline }\end{array}$ & 0.1 \\
\hline 1 & 0 & 1029217 & 173817 & Battery Price & 500 \\
\hline 2 & 0 & 1029217 & 1203035 & $\mathrm{O} / \mathrm{M} \mathrm{Cost}$ & \\
\hline 3 & 500 & 1029217 & 2232752 & Inverter Cost & -700 \\
\hline 4 & 0 & 1029217 & 3261969 & $\begin{array}{l}\text { Off Solar } \\
\text { Days }\end{array}$ & \\
\hline 5 & -700 & 1029217 & 4290486 & & \\
\hline 6 & 500 & 1029217 & 5320204 & Total Revenue & 24875532 \\
\hline 7 & 0 & 1029217 & 6349421 & & \\
\hline 8 & 0 & 1029217 & 7378638 & & \\
\hline 9 & 500 & 1029217 & 8408356 & & \\
\hline
\end{tabular}




\begin{tabular}{|c|c|c|c|c|c|}
\hline 10 & -700 & 1029217 & 9436873 & & \\
\hline 11 & 0 & 1029217 & 10466090 & & \\
\hline 12 & 500 & 1029217 & 11495807 & & \\
\hline 13 & 0 & 1029217 & 12525025 & & \\
\hline 14 & 0 & 1029217 & 13554242 & & \\
\hline 15 & -200 & 1029217 & 14583259 & & \\
\hline 16 & 0 & 1029217 & 15612476 & & \\
\hline 18 & 500 & 1029217 & 17671411 & & \\
\hline 19 & 0 & 1029217 & 18700628 & & \\
\hline 20 & -700 & 1029217 & 19729146 & & \\
\hline 21 & 500 & 1029217 & 20758863 & & \\
\hline 22 & 0 & 1029217 & 21788080 & & \\
\hline 23 & 0 & 1029217 & 22817297 & & \\
\hline 24 & 500 & 1029217 & 23847015 & & \\
\hline 25 & -700 & 1029217 & 24875532 & & \\
\hline
\end{tabular}

This implies that by the end of its lifecycle, this solar system will provide total revenue of around $\$ 24,000$.

Energy Savings through AAC blocks and other passive techniques

This report discusses energy performance, cost-effectiveness, and environmental effect reviews of new energy-efficient material and traditional material was presented for dynamic comparison. The results given below show that there is a large potential for energy savings and improvements through the use of energy-efficient buildings and applications of passive techniques on building envelopes.

\begin{tabular}{|c|c|c|c|c|c|c|c|c|c|c|}
\hline \multirow{6}{*}{$\begin{array}{l}\text { Heating } \\
(\mathrm{kWh} \\
\left.\mathrm{m}^{2} \mathrm{a}\right)\end{array}$} & \multicolumn{3}{|c|}{ Clay Brick Wall Structure } & \multicolumn{3}{|c|}{$\begin{array}{c}\text { Hollow Block Wall } \\
\text { Structure }\end{array}$} & \multicolumn{4}{|c|}{ AAC Block Wall Structure } \\
\hline & $\begin{array}{l}\text { Parame } \\
\text { ters }\end{array}$ & $\begin{array}{l}\text { Conv. } \\
\text { Buildi } \\
\mathrm{ng}\end{array}$ & $\begin{array}{l}\text { Effici } \\
\text { ent } \\
\text { Buildi } \\
\text { ng }\end{array}$ & $\begin{array}{l}\% \\
\text { energy } \\
\text { improve } \\
\text { ment }\end{array}$ & $\begin{array}{l}\text { Conv. } \\
\text { Buildi } \\
\text { ng }\end{array}$ & $\begin{array}{l}\text { Effici } \\
\text { ent } \\
\text { Buildi } \\
\text { ng }\end{array}$ & $\begin{array}{l}\% \\
\text { energy } \\
\text { improve } \\
\text { ment }\end{array}$ & $\begin{array}{l}\text { Conv. } \\
\text { Buildi } \\
\text { ng }\end{array}$ & $\begin{array}{l}\text { Effici } \\
\text { ent } \\
\text { Buildi } \\
\text { ng }\end{array}$ & $\begin{array}{l}\% \\
\text { energy } \\
\text { improve } \\
\text { ment }\end{array}$ \\
\hline & $\begin{array}{l}\text { Heating } \\
\text { demand }\end{array}$ & 26 & 4.0 & \multirow{4}{*}{$25 \%$} & 24 & 4.0 & \multirow{4}{*}{$29 \%$} & 19 & 3.0 & \multirow{4}{*}{$35 \%$} \\
\hline & $\begin{array}{l}\text { Intemal } \\
\text { gains }\end{array}$ & 2.4 & 2.4 & & 2.4 & 2.4 & & 2.4 & 2.4 & \\
\hline & Solar gains & 1.1 & 1.1 & & 1.1 & 1.1 & & 1.1 & 1.1 & \\
\hline & $\begin{array}{l}\text { Windo w } \\
\text { losses }\end{array}$ & 1.32 & 1.28 & & 1.32 & 1.28 & & 1.32 & 1.28 & \\
\hline
\end{tabular}




\begin{tabular}{|c|c|c|c|c|c|c|c|c|c|c|}
\hline & $\begin{array}{l}\text { Extema l } \\
\text { wa } \\
11 \\
\text { losses }\end{array}$ & 11.81 & 1.95 & & 8.99 & 1.85 & & 4.92 & 1.58 & \\
\hline & $\begin{array}{l}\text { Ventilat ion } \\
\text { losses }\end{array}$ & 0.9 & 0.9 & & 0.9 & 0.9 & & 0.9 & 0.9 & \\
\hline \multirow{6}{*}{$\begin{array}{l}\text { Cooling } \\
(\mathrm{kWh} / \\
\left.\mathrm{m}^{2} \mathrm{a}\right)\end{array}$} & $\begin{array}{l}\text { Cooling } \\
\text { demand }\end{array}$ & 109 & 25.0 & \multirow{6}{*}{$40 \%$} & 100 & 25.0 & \multirow{6}{*}{$42 \%$} & 87 & 23.0 & \multirow{6}{*}{$47 \%$} \\
\hline & $\begin{array}{l}\text { Intemal heat } \\
\text { loads }\end{array}$ & 20.0 & 20.0 & & 20.0 & 20.0 & & 20.0 & 20.0 & \\
\hline & $\begin{array}{l}\text { Solar heat } \\
\text { loads }\end{array}$ & 36.3 & 10.3 & & 30.4 & 10.1 & & 22.2 & 9.5 & \\
\hline & $\begin{array}{l}\text { Windo w } \\
\text { losses }\end{array}$ & 0.30 & 3.05 & & 0.23 & 3.03 & & 0.90 & 3.00 & \\
\hline & $\begin{array}{l}\text { Extema l } \\
\text { wa } \\
11 \\
\text { losses }\end{array}$ & 4.62 & 2.89 & & 4.38 & 1.55 & & 3.69 & 0.32 & \\
\hline & $\begin{array}{l}\text { Ventilat ion } \\
\text { losses }\end{array}$ & -0.4 & 6.3 & & -0.4 & 6.3 & & -0.4 & 6.3 & \\
\hline
\end{tabular}

\section{Discussion and policy recommendations}

This study assesses economic values through the use of energy-efficient materials, active and passive techniques in the Residential sector of Australia. As per energy building codes, it was necessary to develop a model that meet the energy-efficient building standards. In this study, energy performance, costeffectiveness, and environmental effects of new energy-efficient and traditional measures were presented for dynamic comparison.

\section{Summary of transformational pathways for energy-efficient NZEBS}

A summary of all techniques and measures discussed in the study, either in literature or proved through results convey the below-mentioned points:

- To control the rapidly increasing energy demand of the residential sector, short-term transitions must be made which includes technology transformation, using energy-efficient appliances (active techniques), and passive techniques like efficient construction materials.

- NZEBs will require the use of renewables like wind catchers, biomass digestors, and most importantly Solar PV systems to cater to the electricity consumption of different devices.

- Solar PV systems can be both centralized and decentralized. Net metering should be integrated to even reduce the load of National Grid. Further as analyzed in the study, it can also be used to generate economic value.

- Wind catchers can be used for extracting both power and mechanical energy that can be used for applications such as grinding or milling. 
- Biogas generated through waste can be used as an alternate fuel.

- Geothermal energy can be used for heat transfer applications.

- Building structure can be improved by the use of energy-efficient materials such as AAC blocks to prevent air leakage and energy storage.

- Building directions can also be adjusted before construction depending on the demographics of the location.

- Window shading can be applied to prevent heat or cooling loss.

\section{Conclusion and future scope}

This study assesses net-zero energy buildings in the climate conditions of Australia. Due to the constantly increasing demand for the building sector due to industrialization, urbanization, and population growth, energy efficiency measures have to be taken to counter it. Simply increasing energy supplies does not serve the purpose as they lead to increased financial debt and the risk of power lock-in. This study covers both active and passive techniques as a means of achieving energy security in the building sector.

During the past few years, the attention given to reducing operational energy demand and resulting environmental impacts in the construction sector has increased significantly. In many countries, national governments have established mandatory policy frameworks, introducing nearly zero-energy buildings in operation as their main building stock ambition. Government incentives are often supported by voluntary certification schemes, which are meant to push building ambitions to reach a (net) zero-energy building level in terms of operation, where the total amount of operational energy used by the building is compensated mainly by renewable energy generation on a typically annual basis. Most of the research in this area has assessed either active or passive techniques but a cumulative assessment along was missing. This study has assessed both active and passive techniques for energy saving alternatives and has further proposed a solar system that can fulfil its sufficient load.

ETU software has been used to create a building design on which loading conditions have been applied to calculate the value of overall heat transfer coefficient "U". Then PHPP software has been used to calculate the effect of passive techniques such as building construction materials to reduce the energy demand of the building and how economically sound it can be. Further, based on the load calculations, a solar system has been designed for the building which explains the total economic benefits that can be achieved through a non zero energy building.

\section{References:}

1.G. Das, M. Aslam, H. Rahman, R. Samoo, N. Hussain, and K. Harijan, "Overcoming electricity crisis in Pakistan : A review of sustainable electricity options," Renew. Sustain. Energy Rev., vol. 72, no. November 2016, pp. 734-745, 2017.

2.A. B. Awan and Z. Ali, "Recent progress in renewable energy - Remedy of energy crisis," Renew. Sustain. Energy Rev., vol. 33, pp. 236-253, 2014.

3.G. Cheung and P. J. Davies, "In the transformation of energy systems : what is holding Australia back ?," Energy Policy, vol. 109, no. December 2016, pp. 96-108, 2017.

4.W. Lin, B. Chen, L. Xie, and H. Pan, "Estimating Energy Consumption of Transport Modes in China Using DEA," pp. 4225-4239, 2015. 
5.T. Wu, M. Zhang, and X. Ou, "Analysis of future vehicle energy demand in China based on a Gompertz function method and computable general equilibrium model," Energies, vol. 7, no. 11, pp. 7454-7482, 2014.

6.Y. Geng, W. Ji, Z. Wang, B. Lin, and Y. Zhu, "Energy \& Buildings Response to the commentary on "A review of operating performance in green buildings : Energy use, indoor environmental quality and occupant satisfaction ' by John H . Scofield," vol. 194, pp. 366-368, 2019.

7.N. Lauzet et al., "How building energy models take the local climate into account in an urban context - A review," Renew. Sustain. Energy Rev., vol. 116, no. February, p. 109390, 2019.

8.R. Dowling, P. Mcguirk, and S. Maalsen, "Energy Research \& Social Science Multiscalar governance of urban energy transitions in Australia : The cases of Sydney and Melbourne," Energy Res. Soc. Sci., vol. 44, no. May, pp. 260-267, 2018.

9.I. Sarbu and C. Sebarchievici, "Review of solar refrigeration and cooling systems," Energy Build., vol. 67 , pp. 286-297, 2013.

10.A. Macintosh and A. Macintosh, "The Australian Government's environmental impact assessment (EIA) regime: using surveys to identify proponent views on cost-effectiveness," vol. 5517, 2012.

11.A. W. Bhutto, A. A. Bazmi, and G. Zahedi, "Greener energy: Issues and challenges for Pakistan Biomass energy prospective," Renew. Sustain. Energy Rev., vol. 15, no. 6, pp. 3207-3219, 2011.

12.C. Du, B. Li, H. Liu, Y. Ji, R. Yao, and W. Yu, "Energy \& Buildings Quantification of personal thermal comfort with localized airflow system based on sensitivity analysis and classification tree model," vol. 194, pp. 1-11, 2019.

13.L. C. Lau, K. T. Lee, and A. R. Mohamed, "Global warming mitigation and renewable energy policy development from the Kyoto Protocol to the Copenhagen Accord - A comment," Renew. Sustain. Energy Rev., vol. 16, no. 7, pp. 5280-5284, 2012.

14.A. Persily, "Challenges in developing ventilation and indoor air quality standards: The story of ASHRAE Standard 62," Build. Environ., vol. 91, pp. 61-69, 2015.

15.S. Hu, D. Yan, J. An, S. Guo, and M. Qian, "Investigation and analysis of Chinese residential building occupancy with large-scale questionnaire surveys," Energy Build., 2019.

16.J. Chen and C. Poon, "Photocatalytic construction and building materials: from fundamentals to applications," Build. Environ., vol. 44, no. 9, pp. 1899-1906, 2009.

17.G. Singh and R. Das, "Comparative assessment of different air - conditioning systems for nearly/net zero - energy buildings,” Int. J. Energy Res., vol. 44, no. 5, pp. 3526-3546, 2020.

18.G. Singh and R. Das, "Energy saving potential of a combined solar and natural gas-assisted vapor absorption building cooling system," J. Sol. Energy Eng., vol. 141, no. 1, 2019.

19.G. Singh and R. Das, "A novel design of triple-hybrid absorption radiant building cooling system with desiccant dehumidification," J. Energy Resour. Technol., vol. 141, no. 7, 2019.

20.G. Singh and R. Das, "Assessment of desiccant assisted compression and absorption based airconditioning systems for hot-dry and composite climates," in Journal of Physics: Conference Series, 2019, vol. 1240, no. 1, p. 12087.

21.A. Figueiredo, J. Figueira, R. Vicente, and R. Maio, "Thermal comfort and energy performance: Sensitivity analysis to apply the Passive House concept to the Portuguese climate," Build. Environ., vol. 103, pp. 276-288, 2016.

22.M. Cellura, F. Guarino, S. Longo, and M. Mistretta, "Energy life-cycle approach in Net zero energy buildings balance: Operation and embodied energy of an Italian case study," Energy Build., vol. 72, pp. 371-381, 2014.

23.O. Saadatian, L. C. Haw, K. Sopian, and M. Y. Sulaiman, "Review of windcatcher technologies," Renew. Sustain. Energy Rev., vol. 16, no. 3, pp. 1477-1495, 2012.

24.F. M. Saiyed, A. H. Makwana, J. Pitroda, and C. M. Vyas, "Aerated Autoclaved Concrete (AAC) Blocks: Novel Material for Construction Industry," Int. J. Adv. Res. Eng. Sci. Manag., vol. 1, no. 2, pp. 21-32, 2014 